\title{
Effect of the addition of mixed B-type protozoa in defaunated rumen of sheep on the degradation and fermentation of different proteins
}

\author{
F Mathieu 1 , J Sénaud 2, JP Jouany 1 \\ IINRA, SRNH, Theix, 63122 St-Genès-Champanelle; \\ 2Université Blaise Pascal, UA 138, Les Cézeaux, 63177 Aubière, France
}

Several in vivo and in vitro studies carried out during the last 15 years showed that refaunation of defaunated animals increases the degradation of microbial and feed proteins in the rumen (see Jouany, 1991, INRA Editions, Sciences Update, 239-261). Thus the total protein flow in the duodenum is severely lowered in faunated animals since the contribution of protozoa to the microbial protein supply in the duodenum is low (Ushida et al, 1986, Br J Nutr, 56, 407-419). This explains why performances are the highest in growing defaunated animals (Bird and Leng, 1984, Br J Nutr, 52, 607-611).

Six adult sheep fitted with a permanent fistula were defaunated (Jouany and Sénaud, 1979, Ann Biol Anim Bioch Biophys, 19, 619-624) during a first period. They were then inoculated with a mixed B-type protozoa during a second period. They were fed a diet composed of barley grain $(600 \mathrm{~g})$, natural grass hay $(600 \mathrm{~g})$ and soyabean meal (150 g), given in two equal meals a day. Measurements started 3 weeks at least after the microbial population stabilized in the rumen. Rumen digesta were collected just before the morning meal with a tube $3 \mathrm{~cm}$ in diameter. A mixture of $100 \mathrm{ml}$ of Mc Dougall saliva and $120 \mathrm{~g}$ of digesta was incubated in fermentors with pure starch (control fermentors), and a mixture of pure starch and different protein sources (lupin seed, soyabean meal, fishmeal) (experimental fermentors). Fermentescibilities of protein sources were calculated from the difference in $\mathrm{NH}_{3}-\mathrm{N}$ productions between control and experimental fermentors (Jouany and Thivend, 1986, Anim Feed Sci Technol, 15, 215-229). Also the $\mathrm{NH}_{3}-\mathrm{N}$ uptake by bacteria was estimated. Ammonia concentrations were measured in the rumen of sheep during the period between the morning and evening meals.

Fermentescibilities of the different nitrogen sources were significantly $(P<0.05)$ increased by the presence of protozoa. The effect of protozoa increased with the insolubility of proteins. This is due to a direct action of protozoa which have a great ability to swallow and digest solid particles and bacteria suspended in the rumen liquid phase. Bacteria are more involved in the fermentation of soluble nitrogenous compounds. In vivo, the concentrations of $\mathrm{NH}_{3}-\mathrm{N}$ in the rumen were significantly higher in refaunated animals throughout the day which confirms higher degradation and fermentation activities.

It was surprising to note that the $\mathrm{NH}_{3}-\mathrm{N}$ uptake by bacteria was significantly higher in refaunated animals which could mean that protozoa stimulated the protein synthesis of bacteria by supplying them with growth factors such as peptides from the degradation of feed proteins.

These results suggest that the ruminal by pass of dietary proteins after feed intake is enhanced by defaunation, from $45 \%$ for high degradable proteins to $400 \%$ when animals are fed low degradable proteins. On the other hand, the net flow of microbial proteins could be decreased by $35 \%$ after defaunation.

\begin{tabular}{|c|c|c|c|}
\hline Animals & Defaunated & Refaunated & Signification \\
\hline \multicolumn{4}{|l|}{ Fermentescibilities (\%) } \\
\hline Lupin seeds & 43.9 & 63.9 & 0.01 \\
\hline Soyabean meal & 20.0 & 33.3 & 0.05 \\
\hline Fishmeal & 3.5 & 17.9 & 0.01 \\
\hline \multicolumn{4}{|l|}{$\mathrm{NH}_{3}-\mathrm{N}$ uptake (mg N) } \\
\hline Control & 35.1 & 47.5 & 0.05 \\
\hline Lupin seeds & 38.4 & 51.7 & 0.05 \\
\hline Soyabean meal & 38.2 & 51.5 & 0.05 \\
\hline Fishmeal & 35.1 & 48.9 & 0.05 \\
\hline In vivo $\mathrm{NH}_{3}-\mathrm{N}(\mathrm{mg} / \mathrm{l}) \mathrm{T}_{5}{ }^{H}$ & 66.3 & 142.6 & 0.05 \\
\hline
\end{tabular}

